\title{
LIFE AND WORK ISSUES IN VOLUNTEER TOURISM: A SEARCH FOR MEANING?
}

\author{
CAMILA V. MÜLLER ${ }^{1}$ \\ (D) https://orcid.org/0000-0002-2458-443X \\ ANGELA B. B. SCHEFFER ${ }^{1}$ \\ (iD) https://orcid.org/0000-0002-3486-8807
}

To cite this paper: Müller, C. V., Scheffer, A. B. B. (2019). Life and work issues in volunteer tourism: A search for meaning? Revista de Administração Mackenzie, 20(1). doi:10.1590/1678-6971/ eRAMG190095

Submission: Apr. 30, 2018. Acceptance: July 10, 2018

Universidade Federal do Rio Grande do Sul (UFRGS), Porto Alegre, RS, Brazil.

\section{(cc) BY




\section{ABSTRACT}

Purpose: This paper aims to understand the motivations involved in volunteer tourism activities and the meaning of the experience to the volunteers in a post-modern context.

Originality/value: Volunteer tourism is a response to the socioeconomic transformations of the 21 st century. It is related to the contemporary search for meaning in the spheres of life and work. In this sense, the study proposes a new reflexive approach to the work debate, integrating issues involving the mobilization of subjectivity and post-modern perspectives.

Design/method/approach: This study is a qualitative investigation with results collected through semi-structured interviews. Content analysis was used to analyze the transcripts.

Findings: The participants are individuals who travel abroad seeking a meaningful tourist experience. As consumers, they welcome life experiences that represent particular aspects of their own identity, while also looking for ways to lend added value to their careers and increase their employability. The volunteer tourism industry mobilizes the production and consumption of such subjectivities, which are related to the search for meaning in the post-modern era. Self-realization, intercultural encounters, and a different perspective on reality are some outcomes of this activity. The meaning of work is itself now a merchandising instrument.

\section{KEYWORDS}

Volunteer Tourism. Postmodernity. Meaning of Work. Life. Work. 


\section{INTRODUCTION}

Postmodern life presents a range of significant issues that affect many social spheres, such as impermanence, unstable relationships, dilution of traditional beliefs and values, weakening of religious and sacred aspects, and difficulties in maintaining bonds (Bauman, 2009; Freitas, 2000). In this increasingly complex, mutable, and unpredictable environment, there are no more guarantees. New labor arrangements have changed subjects' relations with their own work. In this sense, traditional organizational aspects such as security, employment contracts with a long-term perspective, employee loyalty, and internal careers are being replaced by an employability-based psychological contract (Bendassolli, 2007; De Vos \& Van der Heijden, 2015).

Flexible modes of capital accumulation and production processes are now the dominant paradigm (Harvey, 1996; Legge, 1995). A reinvention of ways of life and work is emerging from modes of subjectivism that are also mutable and connected with productive activities (Guattari \& Rolnik, 1986; Lazzarato \& Negri, 2001; Mansano \& Carvalho, 2015). The emphasis is on a new type of labor that is primarily immaterial, which produces and commercializes not only commodities but, increasingly, ways of living embedded within the products (Bauman, 2009; Lazzarato \& Negri, 2001; Mansano, 2009).

Work is now perceived as "a support to realize a reflexive project of yourself: it is used to express a personal style, to cultivate experiences and singular competences, in continual movement around different organizations" (Bendassolli, 2009, p. 394, translated by the authors). Given the impossibility of a long-term relationship with these enterprises, the individual's identity becomes even more disconnected from work and constitutes itself in other aspects of the subject's own life (Bauman, 2009; Bendassolli, 2007). Therefore, consumption becomes the main source for the constitution of the individual's identity, whereas the work is a mean toward this end (Mansano, 2009; Bendassolli, 2007). In addition, the meaning given to work changes and is related to the satisfaction provided by the consumption, not by the work itself.

In this context, the postmodern subject emerges. This subject is, besides other characteristics, individualistic, with multiple identities and a greater propensity to deterritorialization processes. It is also engaged in social relations that are becoming ever more virtual (Freitas, 2000; Bendassolli, 2007). All these aspects lead one to conceive of a subject in constant search for meaning. 
Thus, to attend to these increasingly sophisticated consumer needs, a variety of innovative services arise. The new enterprises involved are specialists in creating and satisfying the constant demands of those individuals who build their own identities through the ways of life associated with consumption of the merchandise (Mansano, 2009; Lazzarato \& Negri, 2001). In the tourism industry, volunteer tourism emerges as a market niche in response to this context. It involves tourism agencies that connect individuals to work as volunteers in a non-governmental organization (NGOs) abroad, located in communities with a situation of poverty and adversity (Wearing, 2001; Wearing \& Poiting, 2009).

Tourist travels are made essentially during vacation periods (Wearing, 2001). The escapist nature of traditional holidays differentiates tourism activities from work issues, as it offers an opportunity to break free from daily work routines (Zahra \& McIntosh, 2007). Thereby, the actual tourism packages intend to reward the individuals for the stress and disturbance caused by the work environment, with marketing stimuli such as "You Deserve it!" (Mansano, 2009).

Furthermore, volunteer tourism has a different nature from the traditional touristic activities. It involves situations in which the consumer faces an uncomfortable reality by experiencing life in a community living in poverty abroad. Thus, the idea of volunteer tourism runs counter to that of vacations for pure pleasure and focuses on experiences that stimulate such feelings as "to make a difference" and "to give back" (Wearing, 2001; Zahra \& McIntosh, 2007).

Its proponents argue that contemporary production relations culminate in new ways of living and in the emergence of postmodern subjects engaged in a constant search for meaning in their lives. Life experiences are now bridging the gap remaining after this range of changes in labor relations. Thus, this investigation aims to understand the motivations involved in the volunteer tourism activity and the meaning of the experience to the volunteer in relation to life and work.

The study is mainly justified for the novelty around volunteer tourism as a tourism niche and as a new form of volunteering. Formal research realized in November 2016 on the Scientific Periodicals Electronic Library (SPELL) revealed a lack of academic studies from Brazilian researchers. The expressions "volunteer tourism" and "turismo voluntário" (as it is in Portuguese) were used without time restrictions and led to only two published papers. However, research on the Portal Periódicos Capes resulted in 56 international articles on the subject, which proves that volunteer tourism is a recognized field of study and has the potential to be explored in Brazil. 
In the following sections, work and life issues will be discussed using a postmodern perspective. Afterward, the methodological path and the main findings of the study are presented, concluding with the discussion.

\section{LIFE AND WORK ISSUES IN A POSTMODERN CONTEXT}

Postmodernity implies a condition of "impermanence", "mutability" and "uncertainty" across several social spheres. The collapse of stable and rigid modern structures provides space for the liquidity in life that shapes contemporary society. According to Bauman (2009):

"Liquid life" is the kind of life commonly lived in our contemporary, liquid-modern society. A "Liquid life" is living in a society in which conditions change faster than the time to consolidate habits, routines and ways to act [...] Liquid life cannot stay on course, as a liquidmodern society cannot keep its shape for long [...] action, conditions and defensive strategies quickly become obsolete [...] (Bauman, 2009, p. 7).

Unlike modernity based on stability and permanence, the postmodern context prevents the solidification of personal projects and ways of living. The subject's identity is decentred (Hall, 2003), not essential and permanent. In addition, the new plural identities could be contradictory (Hall, p. 13) and modify a subject's profile according to their cultural system. In general, these identities are constantly formed and transformed.

The postmodern paradigm presents a new work structuration based on flexible labor. Globalization and rapid technological innovations facilitate the decentralization of production and result in an unpredictable marketplace. Consumers' specialized demands are the focus of productive processes and call for multifunctional subjects able to participate in every production stage. Foremost, these processes involve immaterial labor. The required modifications entail organizational structuring and transformation, which are accompanied by managerial discourses that aim to accommodate capitalist realities by stimulating adaptable postures in the work environment (Harvey, 1996; Ferrer, 1998; Antunes, 1995, 2015).

This mode of production emphasizes the creation of subjective and idealized worlds. In this system, the consumer is now elevated to a primordial production factor (Bauman, 2009; Mansano, 2009). Products are carefully 
designed and created in response to consumers' needs. The desire to belong to these created worlds is fostered by the constant promise of reaching some ideal life and guiding the production-consumption process (Mansano, 2009; Lazzarato \& Negri, 2001). Therefore, marketing industry efforts towards "creating worlds" in which consumers can identify themselves, result in the commercialization of not only commodities, but also ways of living (Lazzarato \& Negri, 2001; Mansano, 2009).

Hence, the flexible labor force contributes to new labor relations and conceptions. As Bendassolli (2007, p.18) states, to be postmodern implies "knowing how to conciliate attachment and soft commitments with the facility to overcome the grave from the rupture of the enterprise." That attachment is also uncertain and unstable, since "results" and "performance" are not guaranteed anymore. Thus, individuals are now responsible for their professional insertion and the constant development of their employability (Bendassolli, 2007; De Vos \& Van der Heidjen, 2015).

The postmodern condition generates a state of constant risk in which subjects cannot assign greater meaning to their work. Destitute of solid identification, the uncertain is constantly present. The gaps remaining within this life and work structuration are filled with hedonic values in a constant search for pleasure; the hopelessness of this fluid life is attenuated by the pleasures provided by the consumer experience. Bauman (2009) emphasizes the central position of consumption as an alternative to the search for meaning. Further, the ownership of merchandise and goods has become a means by which subjects can show themselves and others who they are, who they imagine themselves becoming, their lifestyle and ways of living that they want to be displayed.

Therefore, "the postmodern subject" concept is adopted here. It is an individualistic subject, with multiple identities and goals based on its own interests, "without a sole purpose to dedicate itself, nor a tradition to follow" (Bendassolli, 2009, p. 394). In this context, work has not lost its modern importance, but it is now considered besides other aspects equally relevant to the individuals concerned.

Work and life became indissociable aspects of existence. Once this lack of meaning could not be overcome through work, the search led to the subject's other life`s spheres (Sennet, 2000; Antunes, 2015). Changes in ways of living and working are now related, which demands fresh pursuits, new ways of living and acting, new forms to show oneself and to experience life in this context.

Thus, the tourism industry has a special place in this new economy (Bauman, 2009). In the experiences to be realized during holidays, tourism 
expresses the postmodern ideal of a search for satisfaction or reward for the exhausting daily activities of work (Mansano, 2009). Many tourism packages and options are marketed in a way to satisfy subjects avid for experiences that make sense to their lives. Volunteer tourism emerges as one of the postmodern alternatives intended to mobilize consumers in the search for extraordinary experiences that contrast with their everyday work routines.

\title{
2.1 Volunteer tourism: a response to postmodern demands
}

Volunteer tourism involves international travels that connect the individual to social projects abroad (Wearing, 2001). Tourism agencies are responsible for the partnership with NGOs in the host community. Thus, the activity involves formal volunteering, but in essence is a tourism service (Wilson, 2000; Wilson \& Musick, 1997; Wearing, 2001). It is an industry with a specific supply-demand dynamic, fostered by advertising which promotes the activities developed in the volunteering programmes and the natural attractions of the travel destination (Wearing, 2000; Wearing \& Poiting, 2009).

\begin{abstract}
Volunteer tourism, also known as "voluntourism", refers to tourists who pay to travel to another location where they choose to use their free time to engage in meaningful experiences. They are involved in helping communities by such means as distributing necessities and other resources, restoring and conserving environments, or assisting in field research related to protecting the environment or endangered species of animals $[\ldots]$ personal experience people engage in to fulfill intrinsic motivation which can benefit the participant's life and the host community (Lo \& Lee, 2011, p. 327).
\end{abstract}

The emergency of the volunteer tourism industry is intimately related to the neoliberal ideas of the 21st-century economy (Wright, 2013; Vrasti, 2012; Wearing, 2001; Wearing \& Poiting, 2009). The neoliberal conjecture has characteristics that support the activity, such as 1 . Economic freedom that facilitates the volunteer's mobility around the world; 2 . Globalization as a liberal market which boosts the service and helps in its dissemination; 3. Increasing value added to corporate social responsibility; and 4. The heating up of host community markets (Wright, 2013; Vrasti, 2012; Wearing, 2001).

Non-conventional tourists are the target audience of volunteer tourism's services (Wearing, 2001; Brown, 2005; Caruana, 2007; Zahra \& Mcintosh, 
2007). These tourists have different motivations and goals in their travels, which are intrinsic to the individuals concerned. The central motives could be egoistic or come from a real desire to help the host communities (Lee \& Lo, 2011).

Ulusoy (2016) assumes volunteer tourism as a service and analyses it with the "responsible consumer" lens. As he argues (Ulusoy, 2016), these are tourists who seek a higher purpose, not just an ordinary tourism experience. From this perspective, volunteer tourism is motivated essentially by the desire to give back and to make a difference in the world. The cultural encounters involved are also an identified motivation (Ulusoy, 2016; Wearing, 2001; Brown, 2005; Caruana, 2007).

In the Brazilian context, there are no studies that emphasize the motivation behind volunteer tourism and the meaning given to the activity. This paper contemplates all of these issues and contributes to foster the theme in Brazilian academia. The results presented here are part of a master's thesis.

\section{METHODOLOGICAL PROCEDURES}

This research is a qualitative exploratory study aimed at understanding the phenomenon of volunteer tourism from the participant's perspective. It intends to identify "the people's meaning attributed issues related to things and life" (Godoy, 1995, p. 62).

The study was conducted among 20 volunteer tourism participants. Based on the theoretical concepts in the volunteer tourism literature, the criteria for the sample were individuals that had traveled as volunteers to work in social projects abroad, intermediated by a tourism agency (Wearing, 2001). They should necessarily have engaged in formal volunteering at an NGO, according to Wilson's (2000) definition. Hence, in 2017, between late August and early October, the data collection was initiated. There were some difficulties in finding and accessing these respondents, because of volunteer tourism's national scope; it means that the customer does not need to live in the same city as the tourism agency and the participants were from different Brazilian states.

Therefore, to find the participants for the research, tourism agencies with volunteering abroad services were contacted. As a partner of the research, a specialized volunteer tourism agency, "Exchange do Bem", provided a list of clients that had recently traveled with them. During the data 
collection process, the emergence of a social network among the volunteers was noted (McGehee \& Santos, 2005), which facilitated access to other potential participants. Thus, the snowball method (Bernard, 2017) was considered adequate for the research.

In addition, Volunteer Vacations, another volunteer tourism company, uses its social media platforms (Facebook and Instagram) to promote its activities, using its customers' personal profiles. As Wilson, Goslin and Graham (2012) have reported, Facebook is an effective recruitment tool for researchers. In line with this, Facebook and Instagram were utilized to find other participants for the study.

Semi-structured interviews were used to do the data collection. These interviews integrated open and closed questions in a previously defined script (Boni \& Quaresma, 2005). According to the participant's availability, given that they were not from the same city or state as the researchers, either face-to-face or online interviews were conducted. The ethical procedures were very similar in both processes. All the participants agreed with the free and informed consent terms provided by the researcher to proceed with the study.

The data analysis method was the content analysis according to Bardin (2014). All the interviews were transcribed and the content organized into categories with common characteristics. Semantic criteria were the basis of category construction.

\section{ANALYSIS OF RESULTS}

Before the presentation of volunteer tourism's motivations, it is convenient to introduce the study's participants. Thus, the general characteristics of the participants considered relevant to the study are provided in Figure 4.1. 


\section{(Figure 4.1)}

\section{GENERAL CHARACTERISTICS OF PARTICIPANTS}

\begin{tabular}{|c|c|c|c|c|c|c|c|}
\hline & Sex & Age & $\begin{array}{l}\text { Civil } \\
\text { State }\end{array}$ & $\begin{array}{l}\text { Academic } \\
\text { Education }\end{array}$ & $\begin{array}{l}\text { Occupation Before and } \\
\text { After Volunteer Tourism }\end{array}$ & Country & Program \\
\hline El & F & 19 & Single & $\begin{array}{l}\text { Bachelor in } \\
\text { Advertising } \\
\text { (Freshman) }\end{array}$ & $\begin{array}{l}\text { Before the volunteer } \\
\text { tourism, she worked as a } \\
\text { researcher in an academic } \\
\text { psychology group; after } \\
\text { the trip she started to work } \\
\text { at a Junior Enterprise. }\end{array}$ & $\begin{array}{l}\text { South } \\
\text { Africa }\end{array}$ & $\begin{array}{l}\text { She worked as } \\
\text { a children's } \\
\text { caregiver in an } \\
\text { orphanage. }\end{array}$ \\
\hline E2 & $F$ & 30 & Single & $\begin{array}{l}\text { Majored in } \\
\text { Pharmacy }\end{array}$ & $\begin{array}{l}\text { She works as a pharmacist } \\
\text { at the same company as } \\
\text { before the volunteer } \\
\text { tourism. }\end{array}$ & Ghana & $\begin{array}{l}\text { She worked as a } \\
\text { baby's caregiver } \\
\text { in an orphanage. }\end{array}$ \\
\hline E3 & $F$ & 22 & Single & $\begin{array}{l}\text { Majored in } \\
\text { Advertising }\end{array}$ & $\begin{array}{l}\text { She worked as a freelancer } \\
\text { in brand design before and } \\
\text { after the volunteer tourism. }\end{array}$ & $\begin{array}{l}\text { South } \\
\text { Africa }\end{array}$ & $\begin{array}{l}\text { She worked as a } \\
\text { children's caregiver } \\
\text { in an orphanage. }\end{array}$ \\
\hline E4 & M & 22 & Single & $\begin{array}{l}\text { Bachelor of } \\
\text { International } \\
\text { Relations } \\
\text { (Senior) }\end{array}$ & $\begin{array}{l}\text { He was not working when } \\
\text { he did volunteer tourism. } \\
\text { Today he works as a } \\
\text { volunteer at the Red Cross } \\
\text { and in a refugee } \\
\text { programme. }\end{array}$ & $\begin{array}{l}\text { South } \\
\text { Africa }\end{array}$ & $\begin{array}{l}\text { He worked as a } \\
\text { bird caregiver in } \\
\text { an animal reserve. }\end{array}$ \\
\hline E5 & $F$ & 29 & Single & $\begin{array}{l}\text { Majored in } \\
\text { Biomedical } \\
\text { Science }\end{array}$ & $\begin{array}{l}\text { She works with clinical } \\
\text { research at the same } \\
\text { company as before the } \\
\text { volunteer tourism. }\end{array}$ & $\begin{array}{l}\text { South } \\
\text { Africa }\end{array}$ & $\begin{array}{l}\text { She worked as a } \\
\text { children's caregiver } \\
\text { in an orphanage. }\end{array}$ \\
\hline E6 & M & 28 & Single & $\begin{array}{l}\text { Majored in } \\
\text { Business } \\
\text { Administration }\end{array}$ & $\begin{array}{l}\text { He works as a logistics } \\
\text { manager at the same } \\
\text { company as before the } \\
\text { volunteer tourism. }\end{array}$ & $\begin{array}{l}\text { South } \\
\text { Africa }\end{array}$ & $\begin{array}{l}\text { He worked as an } \\
\text { animal caregiver } \\
\text { in a wildlife } \\
\text { reserve. }\end{array}$ \\
\hline E7 & M & 27 & $\begin{array}{l}\text { Stable } \\
\text { Union }\end{array}$ & $\begin{array}{l}\text { Majored in } \\
\text { Business } \\
\text { Administration }\end{array}$ & $\begin{array}{l}\text { He works in the supply } \\
\text { chain area at the same } \\
\text { company as before the } \\
\text { volunteer tourism. }\end{array}$ & $\begin{array}{l}\text { South } \\
\text { Africa }\end{array}$ & $\begin{array}{l}\text { He worked as a } \\
\text { children's caregiver } \\
\text { in an orphanage. }\end{array}$ \\
\hline E8 & $F$ & 22 & Single & $\begin{array}{l}\text { Bachelor of } \\
\text { Production } \\
\text { Engineering } \\
\text { (Senior) }\end{array}$ & $\begin{array}{l}\text { She is working now and } \\
\text { was not working before } \\
\text { the volunteer tourism. }\end{array}$ & $\begin{array}{l}\text { South } \\
\text { Africa }\end{array}$ & $\begin{array}{l}\text { She worked as an } \\
\text { animal caregiver } \\
\text { in a wildlife } \\
\text { reserve. }\end{array}$ \\
\hline
\end{tabular}

(continue) 


\section{(Figure 4.1 (continuation))}

\section{GENERAL CHARACTERISTICS OF PARTICIPANTS}

\begin{tabular}{|c|c|c|c|c|c|c|c|}
\hline & Sex & Age & $\begin{array}{l}\text { Civil } \\
\text { State }\end{array}$ & $\begin{array}{l}\text { Academic } \\
\text { Education }\end{array}$ & $\begin{array}{l}\text { Occupation Before and } \\
\text { After Volunteer Tourism }\end{array}$ & Country & Program \\
\hline E9 & $F$ & 21 & Single & $\begin{array}{l}\text { Bachelor } \\
\text { of Civil } \\
\text { Engineering } \\
\text { (Sophomore) }\end{array}$ & $\begin{array}{l}\text { She is working now and } \\
\text { was not working before } \\
\text { the volunteer tourism. }\end{array}$ & $\begin{array}{l}\text { South } \\
\text { Africa }\end{array}$ & $\begin{array}{l}\text { She worked as } \\
\text { a children's } \\
\text { caregiver in a } \\
\text { hospital. }\end{array}$ \\
\hline E10 & $F$ & 21 & Single & $\begin{array}{l}\text { Bachelor of } \\
\text { Production } \\
\text { Engineering } \\
\text { (Freshman) }\end{array}$ & $\begin{array}{l}\text { She works at a social } \\
\text { entrepreneurship NGO } \\
\text { from even before the } \\
\text { volunteer tourism. }\end{array}$ & $\begin{array}{l}\text { South } \\
\text { Africa }\end{array}$ & $\begin{array}{l}\text { She worked as } \\
\text { a children's } \\
\text { caregiver in an } \\
\text { orphanage. }\end{array}$ \\
\hline El1 & $F$ & 27 & Single & $\begin{array}{l}\text { Bachelor of } \\
\text { Psychology } \\
\text { (Senior) }\end{array}$ & $\begin{array}{l}\text { She was not working } \\
\text { before the volunteer } \\
\text { tourism. Today she works } \\
\text { as a freelance translator } \\
\text { and as a psychology intern. }\end{array}$ & Namibia & $\begin{array}{l}\text { She worked as } \\
\text { an animal } \\
\text { caregiver in a } \\
\text { wildlife reserve. }\end{array}$ \\
\hline E12 & $F$ & 27 & Single & $\begin{array}{l}\text { Majored in } \\
\text { Pharmacy }\end{array}$ & $\begin{array}{l}\text { She works with health care } \\
\text { at the same multinational } \\
\text { company as before the } \\
\text { volunteer tourism. }\end{array}$ & Ghana & $\begin{array}{l}\text { She worked as } \\
\text { a children's } \\
\text { caregiver in an } \\
\text { orphanage. }\end{array}$ \\
\hline E13 & $F$ & 24 & Single & $\begin{array}{l}\text { Majored in } \\
\text { Mechanical } \\
\text { Engineering }\end{array}$ & $\begin{array}{l}\text { She works with strategic } \\
\text { consulting at the same } \\
\text { company as before the } \\
\text { volunteer tourism. }\end{array}$ & Peru & $\begin{array}{l}\text { She worked as } \\
\text { a children's } \\
\text { caregiver in a girls' } \\
\text { orphanage. }\end{array}$ \\
\hline E14 & $F$ & 22 & Single & $\begin{array}{l}\text { Bachelor of } \\
\text { Tourism } \\
\text { (Senior) }\end{array}$ & $\begin{array}{l}\text { She was not working } \\
\text { before the volunteer } \\
\text { tourism and is not working } \\
\text { now. }\end{array}$ & $\begin{array}{l}\text { South } \\
\text { Africa }\end{array}$ & $\begin{array}{l}\text { She worked as } \\
\text { a children's } \\
\text { caregiver in an } \\
\text { orphanage. }\end{array}$ \\
\hline E15 & M & 24 & Single & $\begin{array}{l}\text { Bachelor of } \\
\text { Business } \\
\text { Administration } \\
\text { (Senior) }\end{array}$ & $\begin{array}{l}\text { He was not working } \\
\text { before the volunteer } \\
\text { tourism and is not working } \\
\text { now. }\end{array}$ & Kenya & $\begin{array}{l}\text { He worked with } \\
\text { orphaned children } \\
\text { and HIV-positive } \\
\text { women. }\end{array}$ \\
\hline E16 & F & 28 & Single & $\begin{array}{l}\text { Majored in } \\
\text { Design }\end{array}$ & $\begin{array}{l}\text { She works with marketing } \\
\text { and visual communication } \\
\text { at the same company as } \\
\text { before the volunteer } \\
\text { tourism. }\end{array}$ & $\begin{array}{l}\text { Thailand } \\
\text { and } \\
\text { South } \\
\text { Africa }\end{array}$ & $\begin{array}{l}\text { She worked in } \\
\text { an elephant } \\
\text { sanctuary } \\
\text { (Thailand) and } \\
\text { as a children's } \\
\text { caregiver in an } \\
\text { orphanage }\end{array}$ \\
\hline
\end{tabular}




\section{(Figure 4.1 (conclusion))}

\section{GENERAL CHARACTERISTICS OF PARTICIPANTS}

\begin{tabular}{|c|c|c|c|c|c|c|c|}
\hline & Sex & Age & $\begin{array}{l}\text { Civil } \\
\text { State }\end{array}$ & $\begin{array}{l}\text { Academic } \\
\text { Education }\end{array}$ & $\begin{array}{l}\text { Occupation Before and } \\
\text { After Volunteer Tourism }\end{array}$ & Country & Program \\
\hline E17 & F & 28 & Single & $\begin{array}{l}\text { Majored in } \\
\text { Industrial } \\
\text { Design }\end{array}$ & $\begin{array}{l}\text { She was working as a } \\
\text { freelancer before the } \\
\text { volunteer tourism. She } \\
\text { has now started her own } \\
\text { business. }\end{array}$ & $\begin{array}{l}\text { South } \\
\text { Africa }\end{array}$ & $\begin{array}{l}\text { She worked as } \\
\text { a children's } \\
\text { caregiver in an } \\
\text { orphanage. }\end{array}$ \\
\hline E18 & F & 20 & Single & $\begin{array}{l}\text { Bachelor of } \\
\text { International } \\
\text { Relations } \\
\text { (Freshman) }\end{array}$ & $\begin{array}{l}\text { She was not working } \\
\text { before the volunteer } \\
\text { tourism and is not working } \\
\text { now. }\end{array}$ & Kenya & $\begin{array}{l}\text { She worked as } \\
\text { an English teacher } \\
\text { for children. }\end{array}$ \\
\hline E19 & F & 21 & Single & $\begin{array}{l}\text { Bachelor of } \\
\text { Law (Senior) }\end{array}$ & $\begin{array}{l}\text { She works at a law firm in } \\
\text { the same company as } \\
\text { before the volunteer } \\
\text { tourism. }\end{array}$ & $\begin{array}{l}\text { South } \\
\text { Africa }\end{array}$ & $\begin{array}{l}\text { She worked as } \\
\text { a children's } \\
\text { caregiver in an } \\
\text { orphanage. }\end{array}$ \\
\hline EZO & F & 32 & Single & $\begin{array}{l}\text { Majored in } \\
\text { Economics }\end{array}$ & $\begin{array}{l}\text { She works with finance at } \\
\text { the same company as } \\
\text { before the volunteer } \\
\text { tourism. }\end{array}$ & $\begin{array}{l}\text { South } \\
\text { Africa }\end{array}$ & $\begin{array}{l}\text { She worked as } \\
\text { a children's } \\
\text { caregiver in } \\
\text { a hospital. }\end{array}$ \\
\hline
\end{tabular}

Source: Elaborated by the authors.

In general, the participants are young adults between 19 and 32 years of age who are experiencing a distinct life and/or career moments. Concerning life moments, there is a group (E1, E3, E4, E8, E9, E10, E13, E14, E15, E18, E19) at the beginning of their professional careers. They are mostly engaged with professional career experiences in the form of graduate internships. Their parents are usually responsible for their life and career investments. They also described themselves as individuals living in a stage of learning and discovering.

Another group (E2, E11, E12, E17, E20) is composed of people with a certain maturity due to a previous life and career experiences. They are aware of their life choices and have some plans for their future.

There is still another group (E5, E6, E7, E16), whose participants are engaged in professional growth. Those individuals hold important positions at their current jobs and consider their careers as the priority aspect of their lives. They also have a competitive lifestyle, striving for excellence in both personal and professional spheres. 
Elements such as personal history, economic context, cultural and social backgrounds and life moments are related to the motivations, the meanings, and the choices made by the participants, affecting their ways of being and living. In their study of volunteer tourism, Lo and Lee (2011) introduced Dann's (1981, p. 205) definition of tourism motivation as "a meaningful state of mind which adequately disposes an actor or a group of actors to travel, and which is subsequently interpretable by others as a valid explanation for such a decision." In this respect, the present research methodology allows a posteriori reflection of the experience.

Hence, in seeking to understand the motivations that led to their volunteer tourism activity, the participants brought reflections about their life moments at the time of trip planning. Their reports presented issues which, in the current interpretation, are related to a postmodern search for meaning. Therefore, based on a deep analysis of the content from transcript interviews (Bardin, 2004), the following categories emerged (Figure 4.2):

\section{(Figure 4.2)}

PARTICIPANT'S MOTIVATIONS

\begin{tabular}{ll}
\multicolumn{1}{c}{ Categories } & \multicolumn{1}{c}{ Explanation } \\
\hline $\begin{array}{l}\text { Tourism with a } \\
\text { Purpose }\end{array}$ & $\begin{array}{l}\text { This motivation concerns typical characteristics of volunteer tourism: } \\
\text { exotic places, opportunities for intercultural encounters, language } \\
\text { practice, and curiosity about the host country. }\end{array}$ \\
\hline Life Experiences & $\begin{array}{l}\text { Life experiences that are related to social actions or some humanitarian } \\
\text { aid experienced by the participant. Voluntary work, family influence, and } \\
\text { life contexts related to social causes are taken here as motivations for } \\
\text { volunteer tourism. }\end{array}$ \\
\hline Crisis Moments & $\begin{array}{l}\text { Situations that impacted the individuals in a way that they search out } \\
\text { volunteer tourism to overcome the crisis. }\end{array}$ \\
\hline Search for Meaning & $\begin{array}{l}\text { The search for significant experiences responsible for giving meaning to } \\
\text { the individual is a motivation for volunteer tourism. }\end{array}$ \\
\hline
\end{tabular}

Source: Elaborated by the authors.

On the following specific topics, the categories will be specifically explored.

\subsection{Tourism with a purpose}

Considering volunteer tourism as "tourism with a purpose", Wearing (2001) assumes the experiences entailed as being intrinsically meaningful 
to the individual. The nature of that "purpose" varies according to the participant's personal interests. In a general way, the act of volunteering is the most relevant aspect of this tourism option.

With the volunteering I tried to give more purpose to my vacations. To say something like: "I went to that place and I did something different and helped other people. That had some meaning. Sounds a cliché, but I can't see another reason to do that" (E7).

Nevertheless, the experiences and adventures facilitated through visiting exotic destinations could be a source of meaning to the volunteer tourist. E20 talks about her desire to undertake a "naturalist's travels" allied to the possibility of volunteering in the places visited. When asked the reasons for not choosing a traditional tourism option, she revealed herself as opposed to traveling "without any purpose". Such participants choose the activity not only by the desire to volunteer, but also for the destination's attractions.

My traveling experiences are much more naturalistic in the way that I pursue energy through nature or from exotic places. And about the volunteer work... I've worked as a volunteer for five years now. So, I cannot think about going out on vacations, go to some city and maybe not doing anything, you know? (E20).

Work-related issues appear around the idea of "tourism as an escape" discussed by Zahra and McIntosh (2007). This perspective considers that working life is inherent to the proper concept of volunteer tourism, because it is realized during a period of vacation when people escape their daily job routines (Wearing, 2001). Therefore, in a way, exotic destinations are isolated from Western civilization in a way that allows participants in volunteer tourism a distance from their habitual activities. Corroborating this argument, E6 claimed as the main trip motivation his necessity to isolate himself from his work problems.

I was there to have fun, you know? I wanted to do something different from my daily routine. My work routine here is really tough. I work really hard, I have too many responsibilities. And I'm a logistics manager [...] So, there are a lot of things that I have to do every day. That's why I always travel on my vacations, that's where I turn my cell phone off [...] You can disconnect from everything (E6). 
Moreover, intercultural contacts are also identified motivations. The self-knowledge process is a relevant outcome of the volunteer tourist's experience. Individuals much concerned about their careers tend to feel some identity emptiness due to their work dedication. Thus, they search for different experiences in a way to recover their true essence, which has been lost in the postmodern turbulence.

During our routines, I think we do so many things that maybe we don't really believe it. We see so many people passing another behind, you know? A bit Machiavellian. When you have those experience when people just want to do good things and help, you kind of connect yourself with who you really are, you know? I swear to God, it is an almost divine experience! It's an experience to find yourself. To be who you really are (E16).

Thus, as Bendassolli (2007) argued, such "non-work" has revealed itself as a source of wellness when the subject utilizes it as a form of selfdetermination. In this sense, everything is related to work and everything adds value. When travel provides intercultural encounters, development of abilities, and language practice, it contributes to the subject's identity construction, which is associated with work. In the reports, market demands were seen as a relevant factor for the choice of destination. The expression "add value" was constantly mentioned to justify the participant's decisions. In relation to the meaning of work, a managerial ethos is perceived. This ethos conceives working as a personal project embedded in the individual's personality (Bendassolli, 2007). Central to the managerial ethos is the idea of the subject as a self-entrepreneur, concerned about developing strategies to become valuable to the market. Therefore, volunteer tourism is seen as an opportunity to gain employability, also entering the individual's identity aspects in a way to "add value", not just only in a personal, but in a professional manner.

So, it was an opportunity to combine knowledge, practice my English, know new cultures and, at the same time, help other people. So, it combines everything in a single trip. The three times that I have traveled abroad, I've always looked for some course, something that could add some value to the trip (E8).

For me, if the trip has no meaning, I prefer, sometimes, not to do it. I always think something like "Man, how can I be a better person after that trip?"; "Will it add some value to my life?" (E6). 


\subsection{Life experiences}

According to Wilson (2000), parents teach their children motivations to undertake voluntary work when they encourage pro-social attitudes by raising them with an exhibition of concrete experienced examples. As adults, those children have a greater propensity to become volunteers. "My parents have been working as a volunteer for a long time, so I've started to volunteer at a really young age" (E19); "My dad is a doctor and my mom is a nurse, so since I was a child, my father brought me and my brother to meet unprivileged people [...] we went to their houses to talk and to really know their reality" (E15).

The findings of Hallmann and Zehrer (2016) indicate that people with a privileged financial situation have a greater propensity for volunteer tourism, not just because they can afford the trip, but also because they demonstrate an intense desire to give back in a positive way to justify their privileged social position. In this study, at some point, the participants experienced a consciousness-raising (McGehee \& Santos, 2005) about the need for less egoistic behavior. "I really wanted to see the poor side, you know? I want to know because it's too easy having a family in good financial health and living in Europe" (E15); "During the last few years, a lot of good things happened in my life, and I wanted to give back to the universe in some way. It is more an internal need, self-realization, you know?" (E17).

In addition, previous volunteer experiences are seen as a motivation for volunteer tourism. Thus, volunteer tourism appears as a step further in the volunteering "career". "I volunteer here too, so I've traveled much more for the experience, like, 'I do it here and I want to see how it is like to volunteer in other countries'” (E9).

Participants with a previous volunteer tourism experience attributed the first experience as a motivation for a second one. E16 defines herself as being so transformed by the opportunity to live and work for a social cause abroad that she needs to repeat the experience another time. As Ulusoy (2016) has argued, volunteer tourism can modify the participant's selfconcept, because of the authentic nature of volunteering abroad. Cognitive connections and interpersonal relationships between other volunteers and the local community could drive behavior changes and new worldviews (Ulusoy, 2016).

That was an amazing experience, I came back completely transformed, because I met some people that were thinking about the same issues 
as me. And I was missing that because I have a lot of friends with a cool head, we chat with each other, but it is not the same. Sometimes I say some things where they say like: "Wow, you're tripping". So, in Thailand, I met some people that could understand me. Then I said: "That's it! Now every travel that I will make in my life must involve volunteer work. When you travel you should work there, you should really experience the living there" (E16).

\subsection{Crisis moments}

Crompton and McKay (1997, p. 427) described tourism motivation as "a dynamic process of internal psychological factors (needs and wants) that generates a state of tension or disequilibrium within individuals." The "state of tension" mentioned by the authors is conceived here as a crisis state. Thus, volunteer tourism is commonly mentioned as an escape valve from relationship breakups. In many cases, the participants experienced moments of reflection that resulted in subjective changes in several personal areas; and they realized that during their relationships, they did not dedicate themselves exclusively to life projects. "I wanted to do something that was really personal, that was my own will" (E2); "Well, now it's time to realize my dreams" (E20).

Zahra and McIntosh (2007) note the intrinsic rewards involved in volunteer tourism activities. They emphasize the volunteer's identity reaffirmation during the experience. With postmodern perspectives, the authors identify the individual's search for meaning through consumption experiences. Thus, the participants refer to volunteer tourism as an investment while adopting a more self-centered posture in a post-crisis moment.

It was a relationship that didn't work [...] in a way I dedicated myself so much to that relationship that I said: I need to take care of myself. And I think that traveling is an investment, you know? A life investment (E20).

E11 experiences a comparable situation, but with some distinct aspects. She was starting a stable union with her partner and felt as though she was losing her autonomy and identity. Volunteer tourism was seen as a consumption experience capable of reinforcing her independence. Bauman (2009) discusses the identity-consumption relation as a feature of postmodernism. Without a 
solid identity reference (Bendassolli, 2007), the satisfaction arising from consumption works as a foundation for subjects to satisfy their needs at the moment (Bauman, 2009). As a result, the subjects construct their identities with the subjectivity involved in these consumption experiences. In E11's conception, traveling to an exotic place, alone, to work as a volunteer with wild animals (a longstanding wish), presents as a relief to the anguish that she felt in experiencing a new life situation. The volunteer tourism experience here had a primordial underlying intention to reinforce the participant's identity, which was previously in a state of crisis.

\subsection{Search for meaning}

The participants related moments of life self-discovery as motivation to undertake volunteer tourism. The travel is a result of self-questioning about their spheres of life in the self-discovery process. This category is distinguished from "crisis moments" by the individual making statements about looking for a special meaning to their lives. In these cases, several life events culminated in the volunteer tourism activity and not a specific trigger as in the previous category.

The "search for meaning" is an aspect constantly mentioned as a motivation in the specialized academic literature on volunteer tourism (Wearing, 2001; Brown, 2005; Caruana, 2007; Zahra \& Mcintosh, 2007). It is a search for self-realization undertaken by individuals who, for no concrete reason, were feeling unsatisfied with their present life condition. These intrinsic dissatisfactions stem from internal self-questioning about their value in the world. E5 declares herself as a satisfied person in diverse life aspects. She has a great prospect for career development, is a healthy person, and has a good financial condition. However, she presents a need which is here interpreted as a "need for self-realization". Thereby, to be satisfied she engages herself in activities which, from her point of view, encourage wellbeing and self-knowledge.

I think that, suddenly, I went to a different life moment where I started to do things like yoga, you know [...] You stop and re-evaluate everything, you know? You stop and think: "Is that what I really want?", you know? It was an internal questioning that was calling for other changes [...] Now I'm feeling a little better, because at the time I traveled, I was really lost. I didn't know what I wanted, not professionally, but for my life. It seems that something was missing, some greater meaning (E5). 
In an analogous way, a search for meaning was noticed in the volunteer work itself. In these cases, the volunteering fills a gap left by the participant's job. This means that when the participants could not find self-realization with their actual jobs, they search for it in activities out of the workplace.

I'm trying to rediscover exactly which finance area I want to work until the end of my life. And I use the volunteer work towards this discovery. So I've already understood that volunteering is work that brings knowledge or abilities to, for example, working with people, working with kids. [...] The volunteering provides pieces of knowledge about myself, you know? [...] As a life aspiration, I already understood that it's what moves me. So, I want to look for something that allows me to make some social impact, some impact on people's life (E20).

The positive social impact on the host communities and the inner satisfaction with the volunteering (Wearing, 2001) produces subjectivities related to the participant's search for meaning. Thus, it is argued that when individuals engage in volunteer tourism, they are also consuming the subjectivities involved in the activity. It is an extraordinary consumption experience (Abrahams, 1986) with a potential for personal transformation. For some participants, the volunteer work cannot itself give the desired meaning, while volunteer tourism appears as an adequate option.

I've already done some volunteer work here, in Brazil. In my city, I did some volunteer work at hospitals, with cancer children. I also donated blood and did some work with unprivileged children. At my job, we did some volunteer work supported by the company too. And I always felt that I needed to do a little more, to make a real difference (E14).

The volunteer tourism is a trip "much more sensitive than contemplative" (E6). Thereby, the search for meaning could be related to the experienced sensations (or results). In a true capitalist society, the act of consumption itself and the money involved in the transaction seem to provide a legitimate solution for the sought meaning. This act meets postmodern demands in which "the consumption offers the possibility to have an experience - in a society where the individuals are constantly looking for sensations, it is important to reward the immediate desires" (Bendassolli, 2007, p. 182).

Consumption thus appears as a viable alternative in the search for meaning when work, which encompasses the individual's several domains, cannot provide it (Bauman, 2009). As mentioned: 
In a certain way, I know that my job has some great relevance, but I can't see myself acting in such an incisive way in people's life. That's something that I really miss. Really, really miss. It's like I'm feeling thirsty for something and couldn't drink that (E16).

That's why I chose [volunteer tourism], you know? Because when we are in our daily routines, sometimes we neglect a lot of things. So, you neglect your family relationship and your good education with the others because of the stress (E12).

Thus, subjects were seen in constant movement towards their identity construction, while keeping a constant eye as to what they can offer the market (their employability). However, the participants were also trying to integrate some meaning into this movement, looking for something greater: tourism that is not just tourism, a different type of volunteer work, and international travel experience in non-traditional circumstances.

\section{CONCLUSION}

The analysis of expressed motivations allowed us to consider volunteer tourism as a result of diverse extrinsic factors - social and cultural contexts, life stories, moments - and intrinsic aspects, such as the subject's desires and pursuits. It is emphasized that participants are young adults with privileged financial situations, prominent levels of academic education, and diverse professional opportunities. They are also familiar with international travel experiences, while volunteer tourism is seen as a different alternative to something that they are already used to.

In many cases, volunteering was already a part of the participant's life as a way of self-realization and a path for personal discovery. Tourism volunteers are individuals who identify themselves with social causes and seek engagement with activities that agree with their own values.

Therefore, the volunteer tourist's choices for vacations, a time commonly designated for leisure, revealed the participants' preference for differentiated tourism and volunteering activities. In the postmodern context (Harvey, 1996; Antunes, 1995; 2015; Ferrer, 1998; Bendassolli, 2007; 2009; 2009b), where ways of living are marketed (Mansano, 2009; Lazzarato \& Negri, 2001), it is noticed that the participant's speeches are responding to marketing calls such as "make a difference" and "to give back" (Wearing, 2001). Responding to these marketing stimuli, the participants intend to seek experiences through travel that fulfill needs intrinsically related to a 
greater life purpose. As a consumption experience, volunteer tourism with its subjectivities is justified as a source of meaning and a way of addressing the world's problems as well as the participant's internal crises.

Thus, this study sought to discuss how changes in labor relations, modes of production, and society have resulted in a broad search for meaning in work and life aspects. As the meaning of work changes over the years, the borders between life and work tend to overlap more and more. In this context, everything should add value, not just for the organizations involved, but also for the subjects, who must seek life experiences that say something about them while constantly raising their employability. Thus, the search for meaning itself becomes a commodity embedded within the subjectivities involved and mobilized through consumption.

It is observed that subjects who aimed to do something meaningful and who were in a search for self-realization, revealed parts of their identities and were constantly paying attention to the labor market's demands. They are postmodern subjects, guided by personal values, constituting themselves through significant life experiences related to promises of satisfaction bound to service offers in the marketplace. They are looking for some greater experience: tourism that is not just a tourist activity, a different kind of volunteering, and international travel that is something more than just a vacation.

Conceptualizing volunteer tourism as a consumption experience that is justified as a source of meaning presents a theoretical contribution. Volunteer work combined with the possibility of self-realization, intercultural exchange, and contacts with communities living in adverse situations permits a reflexive perspective to the volunteer tourist's experience by integrating postmodern notions and subjectivity within production and consumption.

Suggested further research may be to expand and explore the analysis using life history methodology with people who have realized more than one volunteer tourism experience. Studies with foreign tourists who are volunteering in Brazil also provide an opportunity for future research. 


\section{TURISMO VOLUNTÁRIO: UMA EXPERIÊNCIA EM BUSCA DO SENTIDO? VIDA E TRABALHO EM QUESTÃO}

TESUMO

Objetivo: Compreender as motivações do turismo voluntário e qual seria o sentido atribuído à realização dele nas relações com trabalho e vida. Originalidade/valor: Justifica-se pela novidade em torno desse turismo e desse ato de voluntariar, com carência de trabalhos no Brasil. Toma como base as mudanças no modo de produção e no trabalho no século XXI que implicaram uma busca por sentido no trabalho e na vida. Nesse sentido, propõe-se um olhar reflexivo para a temática, integrando noções de pós-modernidade e mobilização de subjetividades.

Design/metodologia/abordagem: Estudo de abordagem qualitativa, com coleta de dados a partir de entrevistas semiestruturadas com 20 sujeitos que participaram de uma experiência de turismo voluntário; análise de dados via análise de conteúdo.

Resultados: Foram identificados sujeitos que buscam experiências significativas de turismo. Como consumidores, buscam experiências de vida que possam dizer algo sobre si mesmos, que agreguem valor e colabore para a empregabilidade deles. Há produção e consumo de subjetividades em torno do turismo voluntário, voltadas para a busca por sentido na pós-modernidade. O próprio sentido do trabalho se torna uma mercadoria.

\section{PALAVRAS-CHAVE}

Turismo voluntário. Pós-modernidade. Sentido do trabalho. Vida. Trabalho.

\section{REFERENCES}

Abrahams, R. D. (1986). An ordinary and extraordinary experience. In V. Turner (ed.), The Anthropology of Experience (pp. 45-72). Chicago, IL: University of Chicago. 
Antunes, R. (1995). Adeus ao trabalho? Ensaio sobre as metamorfoses e a centralidade do mundo do trabalho. Campinas, SP: Cortez.

Antunes, R. (2015). Os sentidos do trabalho: Ensaio sobre a afirmação e a negação do trabalho. São Paulo, SP: Boitempo.

Bardin, L. (2004) Análise de conteúdo. Lisboa: Edições, 70.

Bauman, Z. (2009). Vida líquida. Rio de Janeiro, RJ: Zahar.

Bendassolli, P. F. (2007). Trabalho e identidade em tempos sombrios. Aparecida, SP: Ideias \& Letras.

Bendassolli, P. F. (2009). Recomposição da relação sujeito-trabalho nos modelos emergentes de carreira. Revista de Administração de Empresas, 49 (4).

Bendassolli, P. F. (2009b). Psicologia e trabalho: Apropriações e significados. São Paulo, SP: Cengage Learning.

Bernard, H. R. (2017). Research methods in Anthropology: Qualitative and quantitative approaches. Rowman \& Littlefield.

Boni, V., \& Quaresma, S. J. (2005). Aprendendo a entrevistar: como fazer entrevistas em Ciências Sociais. Em Tese, 2(1), 68-80.

Brown, S. (2005). Travelling with a purpose: Understanding the motives and benefits of volunteer vacationers. Current Issues in Tourism, 8(6), 479-496.

Caruana, R. (2007). A sociological perspective of consumption morality. Journal of Consumer Behaviour, 6(5), 287-304.

Crompton, J. L., \& McKay, S. L. (1997). Motives of visitors attending festival events. Annals of Tourism Research, 24(2), 425-439.

Dann, G. M. S. (1981). Tourism motivation: An appraisal. Annals of Tourism Research, 8(2), 187-219.

De Vos, A., \& Van der Heijden, B. I. (eds.). (2015). Handbook of research on sustainable careers. Cheltenham, UK: Edward Elgar.

Ferrer, F. (1998). Reestruturação Capitalista: Caminhos e descaminhos da tecnologia da informação. São Paulo, SP: Moderna.

Freitas, M. E. (2000). Contexto social e imaginário organizacional moderno. Revista de Administração de Empresas, 40(2), 6-15.

Godoy, A. S. (1995). Introdução à pesquisa qualitativa e suas possibilidades. Revista de Administração de Empresas, 35(2), 57-63.

Gorz, A. (2005). Imaterial (o)-Conhecimento, Valor. São Paulo, SP: Annablume. Guattari, F. \& Rolnik, S. (1986) Micropolitica: Cartografias do desejo. Rio de Janeiro, RJ: Vozes. 
Hall, S. (2003). A Identidade Cultural na Pós-modernidade (7th ed.) Rio de Janeiro, RJ: DP\&A.

Hallmann, K., \& Zehrer, A. (2016). How do perceived benefits and costs predict volunteers' satisfaction? Voluntas: International Journal of Voluntary and Nonprofit Organizations, 27(2), 746-767.

Harvey, D. (1996). Condição pós-moderna: Uma pesquisa sobre as origens da mudança cultura. São Paulo, SP: Loyola.

Janghorban, R., Roudsari, R. L., \& Taghipour, A. (2014). Skype interviewing: The new generation of online synchronous interview in qualitative research. International Journal of Qualitative Studies on Health and Well-being, 9(1), 241-252.

Lazzarato, M. \& Negri, A. (2001) Trabalho imaterial: Formas de vida e produção de subjetividade. Rio de Janeiro, RJ: DP\&A

Legge, K. (1995). Human Resources management. London, UK: McMillan Business.

Lo, A. S., \& Lee, C. Y. (2011). Motivations and perceived value of volunteer tourists from Hong Kong. Tourism Management, 32 (2), 326-334.

Mansano, S. R. V. (2009). Sorria, você está sendo controlado: Resistência e poder na sociedade de controle. São Paulo, SP: Summus.

Mansano, S. R. V. \& Carvalho, P. R. (2015). Políticas de subjetivação no trabalho: Da sociedade disciplinar ao controle. Psicologia em Estudo, 20(4), 651-661.

McGehee, N. G., \& Santos, C. A. (2005). Social change, discourse and volunteer tourism. Annals of Tourism Research, 32 (3), 760-779.

Ulusoy, E. (2016). Experiential responsible consumption. Journal of Business Research, 69(1), 284-297.

Vrasti, W. (2012). Volunteer tourism in the global South: Giving back in neoliberal times. Oxon, UK: Routledge.

Wilson, J. (2000). Volunteering. Annual Review of Sociology, 26(1), 215-240.

Wilson, J., \& Musick, M. (1997). Who cares? Toward an integrated theory of volunteer work. American Sociological Review, 62 (5), 694-713.

Wilson, R. E., Gosling, S. D., \& Graham, L. T. (2012). A review of Facebook research in the social sciences. Perspectives on Psychological Science, 7(3), 203-220.

Wright, H. (2013). Volunteer tourism and its (mis)perceptions: A comparative analysis of tourist/host perceptions. Tourism and Hospitality Research, 13(4), 239-250. 
Zahra, A., \& McIntosh, A. J. (2007). Volunteer tourism: Evidence of cathartic tourist experiences. Tourism Recreation Research, 32(1), 115-119.

Wearing, S. (2001). Volunteer tourism: Experiences that make a difference. Wallingford, UK: Cabi.

Wearing, S., \& Pointing, J. (2009). Breaking down the system: How volunteer tourism contributes to new ways of viewing commodified tourism. In The SAGE Handbook of Tourism Studies (pp. 254-268). London, UK: SAGE Publications.

\section{) AUTHOR NOTES}

Camila V. Müller, Department of Administrative Sciences, Universidade Federal do Rio Grande do Sul (UFRGS); Angela B. B. Scheffer, Department of Administrative Sciences, Universidade Federal do Rio Grande do Sul (UFRGS).

Camila V. Müller is now Doctorate Student at School of Management at Universidade Federal do Rio Grande do Sul (UFRGS); and Angela B. B. Scheffer is now Professor at School of Management at Universidade Federal do Rio Grande do Sul (UFRGS).

Correspondence concerning this article should be addressed to Camila V. Müller, Rua Washington Luiz, 855, Centro Histórico, Porto Alegre, Rio Grande do Sul, Brazil, CEP: 90010-460.

E-mail: mullervcamila@hotmail.com

EDITORIAL BOARD

Editors-in-chief

Janette Brunstein

Silvio Popadiuk

Associated Editor

Alcides Barrichello

Technical Support

Vitória Batista Santos Silva

\section{EDITORIAL PRODUCTION}

Publishing Coordination

Irina Migliari

Layout Designer

Emap

Copyeditor

Irina Migliari (English)

Carlos Villarruel (Portuguese)

Graphic Designer

Libro

Language Editor

Daniel de Almeida Leão (English)

Irina Migliari (Portuguese) 